\title{
Effect of Advertising and Promotion on the Decision of Buyer's Clothes in the Palembang Sunset Extension
}

\author{
M. Dwi Yan Putra \\ Master of Management, Sriwijaya University, Indonesia \\ Corresponding author email: mdwiyanputra@gmail.com
}

\section{Zakaria Wahab}

Lecturer of Magister management Economic Faculty, Sriwijaya University, Palembang Indonesia

Email: zkwahab01@gmail.com

\author{
Marlina Widiyanti \\ Lecturer of Magister management Economic Faculty, Sriwijaya University, Palembang Indonesia \\ Email: marlinawidiyanti68@yahoo.co.id
}

\section{Muchsin Saggaff Shihab}

Lecturer University Bakrie, Jakarta, Indonesia

Email: muchsin.shihab@bakrie.ac.id

\begin{abstract}
This study's main objective was to determine the influence of advertising and sales promotion on purchasing decisions for clothing products at Matahari Palembang Square Extension. The sample of this study was 100 respondents who came from consumers of Matahari Palembang Square Extension. In this analysis, the sampling technique employed non-probability sampling in the form of incident sampling. Multiple regression is the analysis methodology used. Simultaneous effects of the study indicate that advertising and sales promotion variables have a significant effect on customer satisfaction. Partially post-exercise variables do not significantly affect purchasing decisions for clothing products at Matahari Palembang Square Extension.

Keywords---advertising, clothing product, purchasing, sales promotion, supervisory decision.
\end{abstract}

\section{Introduction}

Business in globalization is increasingly dynamic, complex, and uncertain, providing opportunities and challenges. Every company in the industry tries to attract (potential) consumers the attention by providing information about products. The era of globalization has demanded a change in the old paradigm in all fields, one of which is marketing. The increasing level of business competition and uncertainty conditions force companies to achieve a competitive advantage to win the business competition. To achieve this, marketers must apply modern marketing concepts that are market or customer-oriented because they are the spearhead of marketing success (Kotler, 2009; Kotler, 2001; Kotler, 1987; Kotler \& Armstrong, 2001).

One of the retail industries in Indonesia, including department stores or convenience stores, is a type of retail business that provides a wide variety of shopping products and specialty products, including clothing, cosmetics, accessories, household appliances, and furniture. Purchases usually made in each section are treated as a separate buying center to be economical in terms of promotion, purchasing, service, and control. The department store retail company in Indonesia is Matahari Department Store. Matahari Department Store is one of Indonesia's leading retail companies that provides affordable clothing, accessories, beauty, and household products. Matahari partners with trusted suppliers in Indonesia and abroad to provide a combination of high-quality fashion items that are acceptable 
to consumers who are aware of a product's value. Modern and spacious Matahari outlets provide a dynamic and inspiring shopping experience that keeps consumers coming back and helps make Matahari the department store of choice among Indonesia's fast-growing middle class.

Matahari Palembang Square Extension has carried out various kinds of promotions through various media. Matahari commercials through email marketing year-round, media, magazines, banners, and newspapers. Apart from that, Matahari is also present through the Website and Instagram. Matahari always provides information through advertising media during big holidays, Eid, and the end of the year. Various sales promotions are given by Matahari every month, such as discounts on every product purchased. Then purchase two products for the price of one product and provide shopping vouchers for a minimum transaction limit and award points to Matahari members, which can later be used to spend again. If the company carries out appropriate and effective sales promotion activities, consumers' opportunity to shop at Matahari will be greater (Laroche et al., 2003; DelVecchio et al., 2006; Aghara et al., 2018).

The buying process is the behavior of an individual to buying and use a service in the form of products and services that are believed to please him and his willingness to take the risks that could occur (Röglinger et al., 2012; Setianto \& Pratiwi, 2019). In reality, buyers' buying decisions are a series of a variety of structured decisions. Some many considerations and processes need to be considered before making a purchase. Therefore, analyzing the factors that can influence purchasing decisions is worthy of understanding dynamic consumer behavior (Haris Irzandy et al., 2017; Maulida \& Indah, 2020; Dahmiri, 2020).

\section{Method}

The scope of this research is the scope of research in the marketing management group/field. For the research carried out to be more focused on following the phenomena and objectives to be studied, this research's scope is limited only to the problem of advertising and sales promotion on purchasing decisions for clothing products in Palembang Square (Peck \& Childers, 2006; Zsidisin \& Siferd, 2001). The research scope is limited by three main variables: advertising, sales promotion, and buying decisions. This study was all Matahari Palembang Square Extension Palembang consumers who purchased clothing products in the period 2020. The samples taken are expected to have a value that can represent the population of this study. This study's sample was consumers who had shopped once at Matahari Palembang Square Extension within one month (Calder et al., 2009; Buil et al., 2013).

\section{Validity Test Result}

The validity test is a measurement scale called valid when doing what should be done and measuring what should be measured. If the measurement scale is invalid, then it is of no use to the researcher because it does not measure or do what should be done.

\section{Reliability Test}

Reliability demonstrates the stability and reliability of a score. Reliability is distinct from validity since validity focuses on the consistency issue, while the reliability issue is much more concerned with accuracy. Reliability thus involves two main things, namely the consistency of scale and the inner accuracy of size. The accuracy of measurement reveals the quantity to which the measurement becomes unbiased (free of error) and can thus promise consistent measurements across time and a variety of items and instruments. The method used in this reliability test is to use the alpha Cronbach's alpha method, where one questionnaire is considered reliable if Cronbach's alpha> 0.5.

\section{Double Linier Analyses}

Regression analysis helps to understand the impact or apparent marriage between two variables and one predictor variable, so different regression analysis techniques have been used. In this study, the variable advertising (X1), sales promotion (X2), and the dependent variable purchasing decisions (Y). The following regression equation is used by multiple linear regression analysis:

Where:

$$
\mathrm{Y}=\mathrm{a}+\mathrm{b}_{1} \mathrm{X}_{1}+\mathrm{b}_{2} \mathrm{X}_{2}+\mathrm{e}
$$

$$
\begin{aligned}
& \mathrm{Y}=\text { Purchasing Decision Variable } \\
& \mathrm{X} 1=\text { Advertising Variable } \\
& \mathrm{X} 2 \text { = Factor for Direct Marketing }
\end{aligned}
$$




$$
\begin{aligned}
& \mathrm{A}=\text { to Steady } \\
& \mathrm{b} 1=\text { coefficient of regression } \\
& \mathrm{E}=\text { Mistake }
\end{aligned}
$$

\section{Result and Discussion}

Result of validity and reliability test

Table 1

Test validity $(\mathrm{n}=30)$

\begin{tabular}{llllll}
\hline No & Variable & Item & r Count & r Table & Note \\
\hline 1 & Ads (X1) & P1 & 0.462 & 0.367 & Valid \\
& & P2 & 0.575 & 0.367 & Valid \\
& & P3 & 0.600 & 0.367 & Valid \\
& & P4 & 0.580 & 0.367 & Valid \\
& & P5 & 0.764 & 0.367 & Valid \\
& & P6 & 0.790 & 0.367 & Valid \\
& & P7 & 0.740 & 0.367 & Valid \\
& & P8 & 0.775 & 0.367 & Valid \\
& Sale & PP1 & 0.612 & 0.367 & Valid \\
& Promotion & PP2 & 0.631 & 0.367 & Valid \\
& (X2) & PP3 & 0.669 & 0.367 & Valid \\
& & PP4 & 0.629 & 0.367 & Valid \\
& & PP5 & 0.697 & 0.367 & Valid \\
& & PP6 & 0.750 & 0.367 & Valid \\
& & PP7 & 0.672 & 0.367 & Valid \\
3 & PP8 & 0.685 & 0.367 & Valid \\
& Buyer & KP1 & 0.745 & 0.367 & Valid \\
& Decision (Y) & KP2 & 0.792 & 0.367 & Valid \\
& & KP 3 & 0.644 & 0.367 & Valid \\
& & KP 4 & 0.705 & 0.367 & Valid \\
& & KP 5 & 0.792 & 0.367 & Valid \\
& & KP 6 & 0.795 & 0.367 & Valid \\
& & KP 7 & 0.866 & 0.367 & Valid \\
& & KP 8 & 0.816 & 0.367 & Valid \\
& & KP 9 & 0.752 & 0.367 & Valid \\
& KP 10 & 0.777 & 0,367 & Valid \\
& & & & &
\end{tabular}

Source: Data created, 2021

Table 1 shows that all the indicators used to measure the variables used in this study have a correlation efficiency that is greater than the $r$ table. The calculated $r$-value is presented in the Table. These results indicate that all indicators in this study are valid.

Table 2

Reliability test

\begin{tabular}{lll}
\hline Variable & Alpha & Note \\
\hline$A D S(X 1)$ & 0.797 & Reliable \\
Sale Promotion (X2) & 0,829 & Reliable \\
Buyer Decision (Y) & 0,918 & Reliable \\
\hline
\end{tabular}

Source: Data created, 2021 
The reliability test results indicate that all variables have an Alpha coefficient $>0.5$, which means that the items in this research questionnaire can be said to be reliable or reliable as a means of collecting data in research.

\section{Data Analyses}

\section{Partial Test (Uji t)}

This study's t-test was used to partially determine the independent variables' effect (Advertising and Purchase Promotion) on the dependent variable (purchasing decisions). In testing each variable based on processed data from Table 3 below.

Table 3

Coefficient

\begin{tabular}{|c|c|c|c|c|c|c|}
\hline \multicolumn{7}{|c|}{ Coefficient } \\
\hline \multirow[t]{2}{*}{ Model } & \multicolumn{2}{|c|}{ Standardized Coefficients } & \multirow{2}{*}{$\begin{array}{c}\text { Standardized } \\
\text { Coefficients } \\
\text { Beta }\end{array}$} & \multirow[t]{2}{*}{$\mathrm{T}$} & \multirow[t]{2}{*}{ Sig } & \\
\hline & B & Std error & & & & \\
\hline $\begin{array}{ll}1 & \text { (Constant) }\end{array}$ & 18.346 & 3.220 & & 5.698 & & .000 \\
\hline ADS & .132 & .105 & .129 & 1.251 & & .214 \\
\hline Promotion Sale & .576 & .104 & .570 & 5.530 & & .000 \\
\hline a. Dependent Variab & Buying deci & & & & & \\
\hline
\end{tabular}

Source: processed from primary data

\section{Simultaneous test (Uji F)}

Table 4

Test Results F

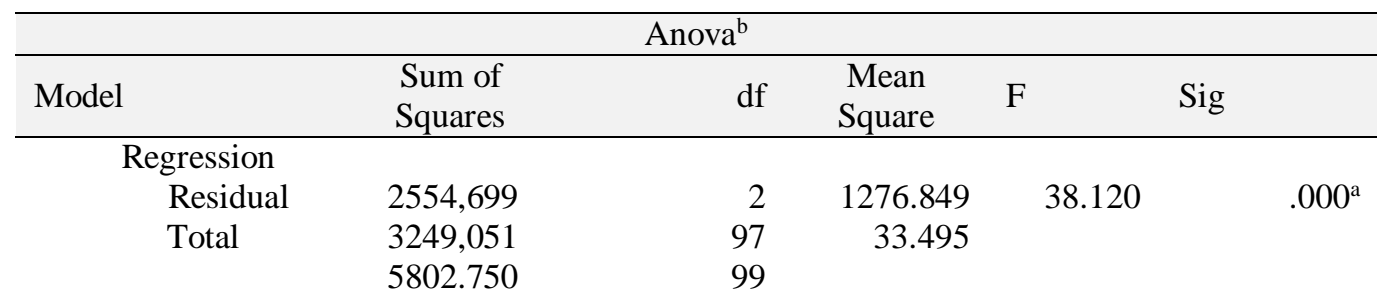

a. Predictors: (Constant), Advertising, Sales Promotion

b. Dependent Variable: Buying Decision

Source: processed from primary data

With a significance value of 0.000 (less than 0.05), the two independent variables, namely Advertising and Sales Promotion, simultaneously influence Buyer Decisions. Based on the analysis results above, it can be concluded that this study already has a good model.

\section{Index of rationality}

The conformity testing objective is to evaluate whether both the linear regression, the variable, and the outcome variable have a normal distribution. The test statistic has become invalid if this assumption holds, and parametric tests could not be used. A good regression model is to have a residual value that is typically distributed. The characteristics of a good regression model include: 


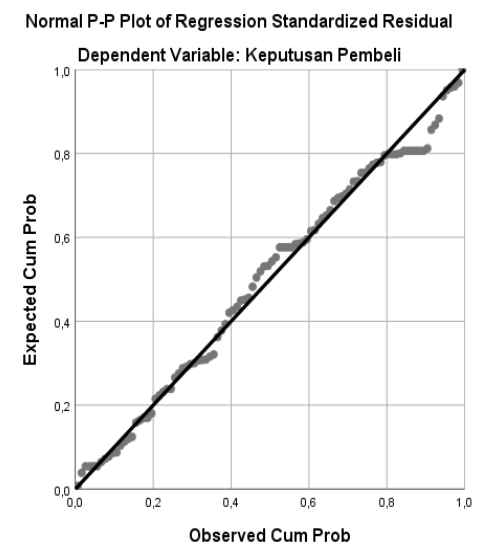

Figure 1. Normal P-P of Regression standardized Residual

It's indeed possible to conclude from the picture above that each point or set of data is still around the horizontal axis. This indicates that the regular model or linear regression satisfies the data normality.

Table 5

One-Sample Kolmogorov-Smirnov Test

\begin{tabular}{llr}
\hline & & $\begin{array}{r}\text { Unstandardized } \\
\text { Residual }\end{array}$ \\
\cline { 3 - 3 } \multicolumn{1}{c}{$\mathrm{N}$} & & 100 \\
\hline Normal Parameters ${ }^{\mathrm{a}, \mathrm{b}}$ & Mean &, 0000000 \\
& Std. & 5,72876093 \\
Most Extreme & Deviation & \\
Differences & Absolute &, 096 \\
& Positive &, 096 \\
Test Statistic & Negative &,- 057 \\
Asymp. Sig. (2-tailed) &, 096 \\
a. Test distribution is Normal. &, $025^{\mathrm{c}}$ \\
b. Calculated from data. & \\
c. Lilliefors Significance Correction. & \\
\hline
\end{tabular}

It's also estimated that perhaps the latent relevant factor is 0.025 on the recommendations of the above equations, which means it is higher than 0.05 , which means there is a typical residual in the linear analysis regression.

\section{Test for Multimillionaires}

The multi-collinearity check aims to test how an association among predictor factors has been identified in the linear regression (independent). There must be no connection between both the predictor factors on a successful linear regression. By staring at the tolerance value and variables derived variable (VIF) and the effects of the analysis using the SPSS request, the multi-collinearity test is performed. If the sensitivity price is more extensive than 0.10 or if the VIF is much less than 10 , this can be inferred that multi-collinearity is not available.

\section{Check for Heteroskedastisity}

The homoscedasticity analysis is to see if there is a variance difference from one recurrent to another test. If there is a difference in variability from the residuals with one event to the next, a regression analysis satisfies the criteria, which is fixed or called homoscedasticity. And use a scatter graph process, homoscedasticity can be achieved by plot 
the ZPRED value (packages depending) with SRESID (its residual value). If there is no particular trend on the chart, such as merging, A good cure is given. Trying to narrow throughout the middle, then widening or conversely.

Study of Multiple Linear Regression

Table 6

Multiple linear regression analysis findings

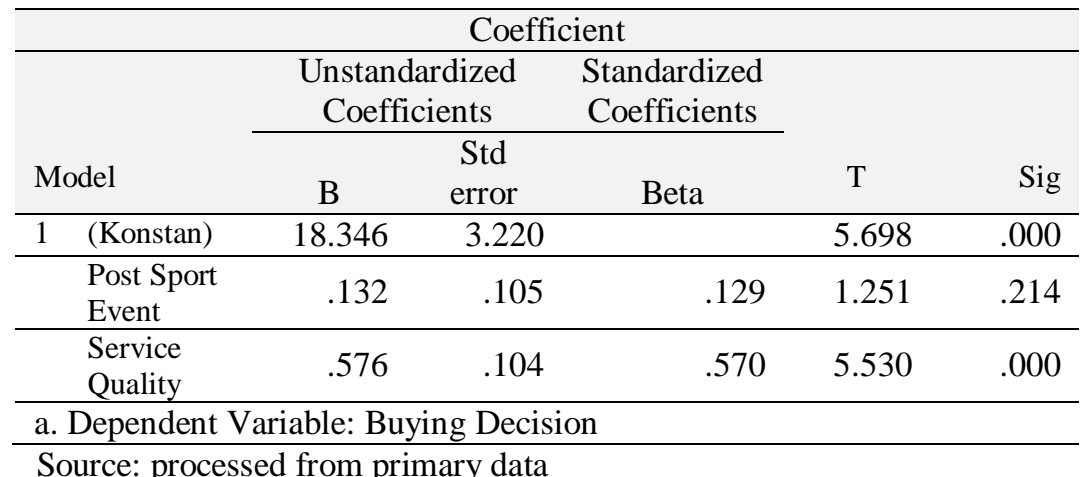

The regression equation model that can be written from these results in the form of a standardized regression equation is as follows:

$$
\mathrm{Y}=18.346+0.132 \mathrm{X} 1+0.576 \mathrm{X} 2
$$

It can be seen from the above equation that perhaps the predictor variable that has a more significant influence on buying decisions is the Sales Promotion variable with a coefficient of 0.576 . Another variable, namely advertising, also has a significant impact on purchasing decisions.

Table 7

Determination Coefficient Test Results

\begin{tabular}{llccc}
\hline \multicolumn{5}{c}{ Model Summary } \\
\hline Model & $\mathrm{R}$ & $\mathrm{R}$ Square & $\begin{array}{c}\text { Adjusted R } \\
\text { Square }\end{array}$ & $\begin{array}{c}\text { Std. Error of the } \\
\text { Estimate }\end{array}$ \\
\hline 1 &, $663^{\mathrm{a}}$ &, 440 &, 429 & 5,78752 \\
\hline \multicolumn{4}{l}{ a. Predictors: (Constant), Advertising, Sales Promotion } \\
\hline \multicolumn{4}{l}{ Source: processed from primary data }
\end{tabular}

The results of calculations can be seen using the Software SPSS 25.0 programs that the decision function (R2) is 0.440 . This means that the variables of Advertising and Sales Promotion have a contribution effect of $44.0 \%$. The other $56.0 \%$ were influenced by other variables not examined in this study, such as place, packaging, atmosphere, and other variables that other researchers could develop.

\section{Discussion}

\section{The effect of advertising on the decision to buy clothing products}

The research description data shows that consumers consider advertisements to have the ability to attract consumers' attention to influence consumers to shop at Matahari. The advertising regression results have a value in the $\mathrm{X}_{1}$ variable of 0.132; therefore, it can be concluded that ads have a somewhat favorable effect on consumer purchasing decisions in preventing some of the problems. Dependent on this quality, it can also be inferred that perhaps the response variables $\mathrm{X}_{1}$ and Dependent $\mathrm{Y}$ get a positive and significant effect. These results indicate that the addition 
of one advertising variable will positively impact the decision to buy clothing products at Matahari Palembang Square. These findings are following research from (Togas et al., 2015; Poluan et al., 2016; Adhy \& Herieningsih, 2019). That notes that advertisement does have a substantial positive impact on buying decisions.

\section{The Impact of Sales Promotion on the Decision to Purchase Clothing Products}

In this Sales Promotion variable, a regression value of 0.576 is obtained, which means that the effect of Sales Promotion occurs significantly on the decision to buy clothes at Matahari. Each addition of the sales promotion variable has a positive influence on purchasing decisions with a coefficient of 0.576 , which means that if the variable on the promotion increases, it will increase the purchasing decision. In this research, the variable has the largest regression value, amounting to 0.576 . This shows that the respondents agree that shopping at Matahari gets discounted promos, two product purchase programs with one product, and getting shopping coupons that influence respondents to shop at Matahari Palembang Square Extension. This result is following the research (Lontoh, 2016; Radjapati et al., 2018). Found that sales promotions have a positive and significant effect on purchasing decisions.

\section{Conclusions}

The following hypotheses can be drawn based on the findings of analysis and discussion as follows:

1) From the results shown, the Advertising (X1) and Sales Promotion (X2) variables simultaneously have a positive and significant effect on the purchasing decision variable (Y) of clothing products at Matahari Palembang Square Extension.

2) From the results shown, the advertising variable (X1) partially has a significant positive effect on the variable purchasing decision variable (Y) clothing products at Matahari Palembang Square Extension.

3) From the results shown, the Sales Promotion variable (X2) partially has a significant positive effect on the variable purchasing decision variable (Y) for clothing products at Matahari Palembang Square Extension.

4) The variable that has the largest contribution in influencing the decision to purchase clothing products at Matahari is the X2 sales promotion variable, which can be seen from the results of SPSS 25.

From the conclusions of the research results that have been obtained, the authors provide some suggestions as follows:

1) Simultaneously, sales promotion and advertising can influence the purchasing decisions of clothing products at Matahari, so this strategy should be maintained and further improved. The influence of advertising and sales promotions can influence consumer purchasing decisions to shop at Matahari.

2) From this research, it is found that the most dominant variable is the Sales Promotion variable. It is hoped that Matahari can maximize this promotion strategy because sales promotion is an essential factor for consumers to shop at Matahari Palembang Square Extension.

3) For further researchers interested in researching this research, it can be recommended to expand the research sample or add indicators in the variable dimensions in this study.

\section{Acknowledgments}

Many thanks to many parties who offered assistance to finish this paper as scheduled during the writing time. As part of our roles and responsibilities, we carry out this study as part of our author's scholarly completeness. We are grateful to two anonymous reviewers and editors who have cooperatively support this project entitled "The Effect of Advertising and Promotion on The Decision of Buyer's Clothes in The Palembang Sunset Extention. 
References

Adhy, M. A. R. S., \& Herieningsih, S. W. (2019). Pengaruh Terpaan Iklan Bukalapak di Televisi dan Promosi Penjualan terhadap Keputusan Pembelian di Situs Jual Beli online Bukalapak. Interaksi Online, 7(4), 105-112.

Aghara, V. N., Nwaizugbo, I. C., Oparah, P. C., \& Ifeanyichukwu, C. D. (2018). Sales promotion as a leverage strategy for improving sales and profitability in alcohol beverage industry. International research journal of management, IT and social sciences, 5(4), 18-25.

Buil, I., De Chernatony, L., \& Martínez, E. (2013). Examining the role of advertising and sales promotions in brand equity creation. Journal of business research, 66(1), 115-122. https://doi.org/10.1016/j.jbusres.2011.07.030

Calder, B. J., Malthouse, E. C., \& Schaedel, U. (2009). An experimental study of the relationship between online engagement and advertising effectiveness. Journal of interactive marketing,23(4), 321-331. https://doi.org/10.1016/j.intmar.2009.07.002

Dahmiri, D. (2020). Pengaruh sosial media marketing dan brand equity terhadap minat beli. KINERJA, 17(2), 194201.

DelVecchio, D., Henard, D. H., \& Freling, T. H. (2006). The effect of sales promotion on post-promotion brand preference: A meta-analysis. Journal of retailing, 82(3), 203-213. https://doi.org/10.1016/j.jretai.2005.10.001

Haris Irzandy, M. A., Suharyono, S., \& Arifin, Z. (2017). Pengaruh Ekuitas Merek Terhadap Minat Beli Dan Dampaknya Pada Keputusan Pembelian (Survei pada Pengguna Kartu Perdana SimPATI Khusus Internet di GraPARI Telkomsel Cabang Kota Malang). Jurnal Administrasi Bisnis, 51(1), 151-158.

Kotler, P. (1987). Manajemen Pemasaran: Analisis, Perencanaan, Dan Pengendalian. Erlangga.

Kotler, P. (2001). Manajemen Pemasaran di Indonesia: Analisis. Perencanaan, Implementasi dan Pengendalian, Edisi II, Jakarta: Salemba Empat.

Kotler, P. (2009). Marketing Management. Pearson Prentice Hall.

Kotler, P., \& Armstrong, G. (2001). Prinsip-prinsip pemasaran. Jakarta: Erlangga.

Laroche, M., Pons, F., Zgolli, N., Cervellon, M. C., \& Kim, C. (2003). A model of consumer response to two retail sales promotion techniques. Journal of Business research, 56(7), 513-522. https://doi.org/10.1016/S01482963(01)00249-1

Lontoh, M. N. (2016). Analisis pengaruh bauran promosi terhadap keputusan pembelian mobil Toyota pada PT. Hasjrat Abadi Manado Cabang Tendean. Jurnal Berkala Ilmiah Efisiensi, 16(1).

Maulida, Z., \& Indah, D. R. (2020). Pengaruh Kesadaran Merek, Asosiasi Merek Dan Persepsi Kualitas Terhadap Kepuasan Konsumen Dan Implikasinya Terhadap Niat Membeli Ulang Vitamin Merek Holisticare Ester C Pada Masa Pandemi Covid 19 Di Kota Banda Aceh. Jurnal Manajemen dan Keuangan, 9(3), 332-351.

Peck, J., \& Childers, T. L. (2006). If I touch it I have to have it: Individual and environmental influences on impulse purchasing. Journal of business research, 59(6), 765-769. https://doi.org/10.1016/j.jbusres.2006.01.014

Poluan, J. G., Lumintang, G. G., \& Untu, V. N. (2016). Pengaruh periklanan terhadap keputusan pembelian minuman coca cola (studi kasus pada pt. bangun wenang beverage company manado). Jurnal EMBA: Jurnal Riset Ekonomi, Manajemen, Bisnis dan Akuntansi, 4(3).

Radjapati, T. Y., Tumbuan, W. J., \& Soepeno, D. (2018). Pengaruh Periklanan, Promosi Penjualan Dan Personal Selling Terhadap Keputusan Pembelian Kartu Telkomsel Di Tobelo. Jurnal EMBA: Jurnal Riset Ekonomi, Manajemen, Bisnis dan Akuntansi, 6(4).

Röglinger, M., Pöppelbuß, J., \& Becker, J. (2012). Maturity models in business process management. Business process management journal.

Setianto, R. H., \& Pratiwi, A. (2019). Working capital management in Indonesia: An analysis on overinvestment and underinvestment firms. Gadjah Mada International Journal of Business, 21(1), 1.

Togas, N. M., Sepang, J. L., \& Wenas, R. S. (2015). Periklanan, Penjualan Pribadi, Promosi Penjualan, Dan Publisitas Terhadap Keputusan Pembelian Pada Penerbit ANDI Cabang Manado. Jurnal EMBA: Jurnal Riset Ekonomi, Manajemen, Bisnis dan Akuntansi, 2(4).

Zsidisin, G. A., \& Siferd, S. P. (2001). Environmental purchasing: a framework for theory development. European Journal of Purchasing \& Supply Management, 7(1), 61-73. https://doi.org/10.1016/S0969-7012(00)00007-1 